Vol. 6 (5), pp. 095-102, November, 2016

ISSN: 2276-7762; ICV: 5.99

Copyright (C2016, the copyright of this article is retained by the author(s)

DOI Link: http://doi.org/10.15580/GJBS.2016.5.111816206

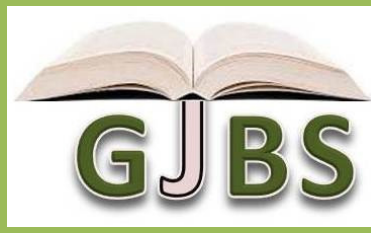

http://gjournals.org/GJBS

\title{
Field Studies on Mosquitoes (Diptera: Culicidae) in the Western Coast of Saudi Arabia: Influence of Temperature, pH and Salinity of the Breeding Water on Larval Abundance
}

\author{
MOSTAFA Ibrahim Hassan', HAMDY Al Hossiny Al Ashry², \\ MOHAMMED Shobrak ${ }^{3}$, MOHAMED Amin Kenawy ${ }^{\star 4}$
}
${ }^{1}$ Prof. of Medical Entomology, Zoology Department, Faculty of Science (boys), Al-Azhar University, Nasr City, Cairo, Egypt.
${ }^{2}$ Sector manager of pest control project, TRAP Pest Control and Garden Maintenance Co. Ltd., Jeddah, Saudi Arabia.
${ }^{3}$ Prof. of Animal Ecology, Biology Department, Science College, Taif University, Taif 21974, Saudi Arabia
${ }^{4}$ Prof. of Medical Entomology, Department of Entomology, Faculty of Science, Ain Shams University, Abbassia, Cairo 11566, Egypt
1Email: mostafa012@gmail.com; Mob: +2-01223840969, ²Email: ashryhamdy @yahoo.com; Mob: +966-599230180, ${ }^{3} \mathrm{E}$ mail: shobrak @saudibird.org; Mob: +966-505721001,
${ }^{4}$ Email: mohamedkenawy330 @gmail.com, Mob: +2-01223540005

Article No.: 111816206

Type: Research

DOI: 10.15580/GJBS.2016.5.111816206

Submitted: 18/11/2016

Accepted: $25 / 11 / 2016$

Published: 30/11/2016

${ }^{*}$ Corresponding Author

Mohamed Amin Kenawy

E-mail: mohamedkenawy330@

gmail.com

Phone: +202- 24821096, Ext. 711,

Fax: +202- 22642123,

Mob: +2- 01223540005

Keywords:

Mosquito larvae, Breeding water

temperature, ph, salinity, Saudi Arabia
The knowledge of the characteristics of the breeding habitats and the environmental factors affecting mosquito abundance can help in designing optimal vector control strategies, for this, mosquito larvae were biweekly surveyed for two years in six localities representing the western coast of Saudi Arabia. Temperature, $\mathrm{pH}$ and salinity of the breeding water were measured to examine the effect of such factors on larval density. Cx. quinquefasciatus, $C x$. theileri, Cx. pipiens and Cs. longiareolata had wider temperature ranges (15 to $33^{\circ} \mathrm{C}$ ) than Cx. tritaeniorynchus, St. aegypti, An. multicolor, Cx. perexiguus, $C_{x}$. sitiens and An. d'thali (17 to 33 ) and $C x$. torrentium $\left(26^{\circ} \mathrm{C}\right)$. St. aegypti, Cx. pipiens, Cx. quinquefasciatus and $C s$. longiareolata breed in either acidic or alkaline water ( $\mathrm{pH}: 4.2$ to 9.5) while the rest of species breed entirely in alkaline water (pH: 7.0 to 9.6). St. aegypti, Cx. tritaeniorynchus, $C x$. quinquefasciatus, Cx. theileri and Cs. longiareolata had wider salinity ranges (154 to 1990 ppm) than the other species (611 to 1972 ppm), i.e., all species breed in fresh / brackish water. Multiple Regression analysis indicated that densities (No larvae / 10 dips): (1) of the tested species: Cx. pipiens, $C x$. quinquefasciatus $(\mathrm{P}<0.05), C x$. tritaeniorynchus $(\mathrm{P}<0.01)$, Cx. theileri, Cx. sitiens, An. multicolor, St. aegypti and Cs. Iongiareolata were directly related to temperature ( $b=0.32$ to 6.15$)$, (2) of $C x$. pipiens, $C x$. theileri, Cx. sitiens, An. multicolor and St. aegypti were indirectly related to $\mathrm{pH}(\mathrm{b}=-0.13$ to -74.57$)$, while those of the other species were directly related to $\mathrm{pH}(\mathrm{b}=2.44$ to 23.60$)$ and $(3)$ of $C x$. quinquefasciatus, $C x$. theileri and St. aegypti were indirectly related to salinity $(b=-0.002$ to -0.017$)$, while those of the other species were directly related to salinity $(b=0.002$ to 0.074$)$. 


\section{INTRODUCTION}

The Western part of the Kingdom of Saudi Arabia " $16^{\circ}$ and $33^{\circ} \mathrm{N}, \quad 34^{\circ}$ and $56^{\circ}$ E" (Wikipedia: https://en.wikipedia.org/wiki/KSA) includes the west coast, north of Asir. It contains a mountain chain ( with peaks

rising to 3,000 meters, running south to north and decreasing gradually in elevation as it moves northward) and the coastal plain bordering the Red Sea. It also includes the most cosmopolitan city of Jeddah which is the main port for thousands of pilgrims as the first step on their trip to Holy Cities of Mecca (to the east) and Al Madinah (to the north).

In the mountains above Mecca and Jeddah is the town of Taif. Its elevation gives it a climate far cooler and pleasanter than either Jeddah or Mecca and without the uncomfortable humidity of the former cities. The coastal area of the Western Region is notorious for its humidity, with summer temperatures rising to above $40^{\circ} \mathrm{C}$. Three regions representing this part: (1) The Mecca Region (Makkah) " $21^{\circ} 25^{\prime} \mathrm{N} 39^{\circ} 49^{\prime} \mathrm{E}$ " is the most populous region in Saudi Arabia, (2) The Al Madinah Region " $25^{\circ} 0^{\prime} \mathrm{N} 39^{\circ} 30^{\prime}$ " is located along the Red Sea coast. and (3) Tabouk (Tabuk) Region " $28^{\circ} 0^{\prime} \mathrm{N} 37^{\circ} 0^{\prime} \mathrm{E}$ " is located along the north-west coast of the country, facing Egypt across the Red Sea.

Fifty three mosquito species belonging to 11 genera: Anopheles, Culex, Lutzia, Ochlerotatus, Stegomyia, Aedes, Aedimorphus, Fredwardsius, Culiseta, Uranotaenia and Orthopodomyia are indigenous in the Kingdom, of which 35 species: 14 Anopheles, 14 Culex, 2 Ochlerotatus and 1 species each of Lutzia, Stegomyia, Aedimorphus, Culiseta and Uranotaenia are present in the western part of the Kingdom (Al Ali et al., 2008; Al Ghamdi et al., 2008; Alahmed et al., 2009; Kheir et al., 2010; Al Ahmad et al., 2011; Khater et al., 2013; Alikhan et al., 2014; Mahyoub et al., 2015; Hassan et al., in prep).

Several mosquito species of the western part are implicated as vectors of diseases either in this part or in the other parts of the Kingdom: $C x$. pipiens may act as a potential vector of bancroftian filariasis (Omar, 1996) and a vector of West Nile Virus (Al-Ali et al., 2008). Cx. tritaeniorhynchus and Am. v. arabiensis are the main proven vectors of Rift Valley Fever virus (Jupp et al., 2002; Miller et al., 2002). Sindbis virus was isolated from $C x$. univittatus (Cx. perexiguus) in the Eastern Region (Wills et al., 1985). Ae. aegypti (St. aegypti) is the primary vector of Dengue fever (El-Badry and Al-Ali, 2010). An. arabiensis, An. stephensi, An. sergentii and An. fluviatilis act as the malaria vectors (Daggy, 1959; Al- Seghayer et al., 1999; Abdoon and Alshahrani, 2003).
To control mosquitoes, a good knowledge and understanding of the relevant biology and ecology of the target species is of paramount importance (Seghal and Pillai, 1970; Gimnig et al., 2001). The knowledge of the ecological characteristics of the breeding habitats and the environmental factors affecting mosquito abundance can help in designing optimal vector control strategies (Overgaard et al., 2001). Moreover, understanding climatic factors (temperature, relative humidity and rainfall) influencing adults and larvae is the first step to control over mosquito vector distribution and abundance (Jemal and Al-Thukair, 2016).

Generally, mosquitoes breed in a wide range of habitats with different types of waters. The physical and chemical nature of the water probably determines the selection of the breeding sites (Seghal and Pillai, 1970). It was reported (Piyaratnea et al., 2005) that breeding water quality is an important determinant of whether female mosquitoes will lay their eggs, and whether the resulting immature stages will successfully complete their development to the adult stage.

There are no available studies on physical and chemical factors mainly temperature, $\mathrm{pH}$ and salinity relative to mosquito breeding in Saudi Arabia except that of Al-Ahmed et al. (2010) who suggested that the salt content and $\mathrm{pH}$ have no significant effects on the larval distribution of different species in Najran and of Jemal and Al-Thukair (2016) who examined the relationship between larval / adult mosquito abundance and climatic factors (temperature, relative humidity and rainfall) in the Eastern Province. So that, this study was undertaken to examine the ranges of temperature, $\mathrm{pH}$ and salinity of mosquito larval habitats and relation of such factors with the occurrence and abundance of a particular mosquito species in six localities representing the western coast of Saudi Arabia.

\section{MATERIALS AND METHODS}

\section{The Study Area}

The study was carried out in four sea ports (Jeddah: $21^{\circ} 32^{\prime} 36^{\prime \prime} \mathrm{N} 39^{\circ} 10^{\prime} 22^{\prime \prime} \mathrm{E}$, Yanbu: $24^{\circ} 05^{\prime} \mathrm{N} 38^{\circ} 00^{\prime} \mathrm{E}$, Duba: $27^{\circ} 20^{\prime} 57.3^{\prime \prime} \mathrm{N} 35^{\circ} 41^{\prime} 46.2^{\prime \prime} \mathrm{E}$ and Haql: $29^{\circ} 17^{\prime} \mathrm{N} 34^{\circ} 56^{\prime} \mathrm{E}$ ) and 2 cities (Taif: $21^{\circ} 26^{\prime} \mathrm{N} 40^{\circ} 21^{\prime} \mathrm{E}$ and Mecca: $21^{\circ} 30^{\prime} \mathrm{N} 41^{\circ} 0^{\prime} \mathrm{E}$ ) representing the 3 regions of the western part of the Kingdom namely Mecca, Al Madinah and Tabouk (Fig 1). In each locality, certain sites were selected for sampling mosquitoes. Each site was biweekly surveyed during the period from January 2013 to December 2014. 


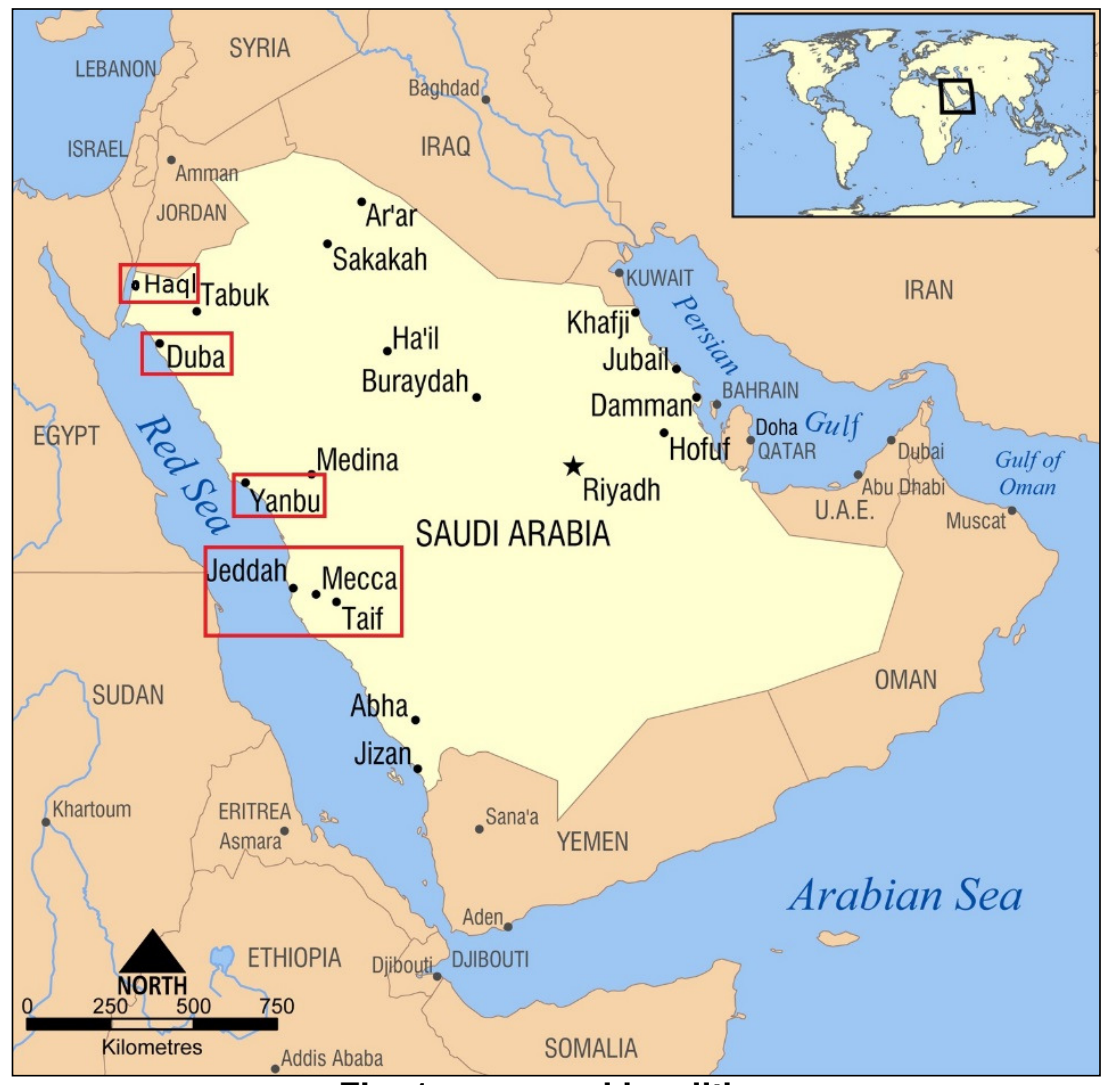

Fig. 1: surveyed localities

\section{Mosquito Sampling}

The larvae were sampled in the water bodies by dipping using a plastic dipper, $125 \mathrm{~mm}$ in diameter with a $90 \mathrm{~cm}$ aluminum telescoping handle. Three samples of 10 dips (a survey unit, SU) per breeding site were taken. Collected larvae were placed in labeled plastic bags (Nasco whirl pack 4002 filline U.S.A) and transported to the laboratory in a picnic ice box containing cold water to prevent overheating. At the laboratory, 3rd and 4th larval instars were killed with hot water and preserved in labeled specimen tubes containing $70 \%$ ethyl alcohol to be ready for identification. Collected larvae were identified according to keys of Mattingly and Knight (1956) and Al Ahmad et al. (2011). Along with larval collection, the water temperature, $\mathrm{pH}$ and salinity (ppm) were measured in situ using $\mathrm{pH} / \mathrm{EC} / \mathrm{TDS} /$ Temperature meters (Model Hi 98130, Hanna instruments Co. USA).

\section{Data Analysis}

The compiled ranges of water temperature, $\mathrm{pH}$ and salinity of the different breeding habitats were calculated for each larval species in all studied localities. Multiple Regression analysis was used to examine the relation of larval density (No / SU) with the temperature, $\mathrm{pH}$ and salinity of the breeding water. The regression equations were in the form of Larval density $=a+b_{1}$ temperature + $b_{2} p H+b_{3}$ salinity where $a=$ constant (intercept), $b_{1}-b_{3}$ are the slopes (regression coefficients). The slopes were tested for deviation from 0 by t-test. The PAST (PAleontological Statistics Version 2.08, Hammer et al., 2001) computerized software was used for statistical analysis.

\section{RESULTS AND DISCUSSION}

\section{Ranges of the Breeding Water Temperature, $\mathrm{pH}$ and Salinity}

Mosquitoes breed in a wide range of habitats with different types of waters that are known to be specific for certain species. The prevailing physicochemical parameters in these habitats are important factors for survival and development of mosquitoes (Oyewole et al., 2009 ) and probably determine the selection of the breeding sites

(Seghal and Pillai, 1970). Moreover, It was reported that the breeding water quality is an important determinant of whether female mosquito will lay their eggs, and whether the resulting immatures will successfully complete their development to the adult stage (Piyaratnea et al., 2005). Mosquito immatures are poikilothermic and therefore, their activity depends to a large extent on the temperature of the water they inhabit. Besides nutrition, temperature is the main factor that affects the development and growth of mosquito larvae (White, 
1974). In general, an increase in water temperature will result in faster development of aquatic stages, but will decrease the size of the emerging adults (Bayoh and Lindsay, 2003), decrease larval survival and at higher temperatures fewer adults are produced due to increased mortality (Bayoh and Lindsay, 2004).

In the present study (Figure 2), $C x$. quinquefasciatus $\left(15\right.$ to $\left.33^{\circ} \mathrm{C}\right)$, Cx. theileri $\left(15\right.$ to $\left.31^{\circ} \mathrm{C}\right)$, Cx .pipiens ( 15 to $29^{\circ} \mathrm{C}$ ) and Cs. longiareolata (15 to 29 $\left.{ }^{\circ} \mathrm{C}\right)$ had wider temperature ranges than those for $C x$ tritaeniorynchus $\left(17\right.$ to $\left.31^{\circ} \mathrm{C}\right)$, St. aegypti $\left(17\right.$ to $\left.33^{\circ} \mathrm{C}\right)$, An. multicolor $\left(18\right.$ to $\left.28^{\circ} \mathrm{C}\right), C x$. perexiguus $(20$ to 26 ${ }^{\circ} \mathrm{C}$ ), Cx. sitiens (22 to $33^{\circ} \mathrm{C}$ ) and An. d'thali (28 to 33 $\left.{ }^{\circ} \mathrm{C}\right)$. Cx. torrentium collected only from water had temperature of $26^{\circ} \mathrm{C}$. In general, a compiled temperature range of 15 to $33^{\circ} \mathrm{C}$ (mean $24.0^{\circ} \mathrm{C}$ ) was observed for the eleven reported species altogether. More or less similar range of 16.4 to $27.7^{\circ} \mathrm{C}$ was found suitable for production and survival of larvae (Culex, Aedes and Anopheles genera) in the Eastern Province, Saudi Arabia and in the summer season, the average temperature in this area became greater than $35^{\circ} \mathrm{C}$ which is unsuitable for larval growth (Jemal and AlThukair, 2016). Different temperature ranges were reported in several Egyptian Governorates such as 21 to $29^{\circ} \mathrm{C}$ (Kenawy et al., 1998), 18 to $30^{\circ} \mathrm{C}$ (Abdel-Hamid et al., 2009), 23 to $28^{\circ} \mathrm{C}$ (Abdel-Hamid et al., 2011a), 22 to $28{ }^{\circ} \mathrm{C}$ (Abdel-Hamid et al., 2011c) and 17 to $30^{\circ} \mathrm{C}$ (Kenawy et al., 2013). Moreover, WHO (1975) stated that the average optimum temperature for development of most mosquito species is around $25-27^{\circ} \mathrm{C}$.

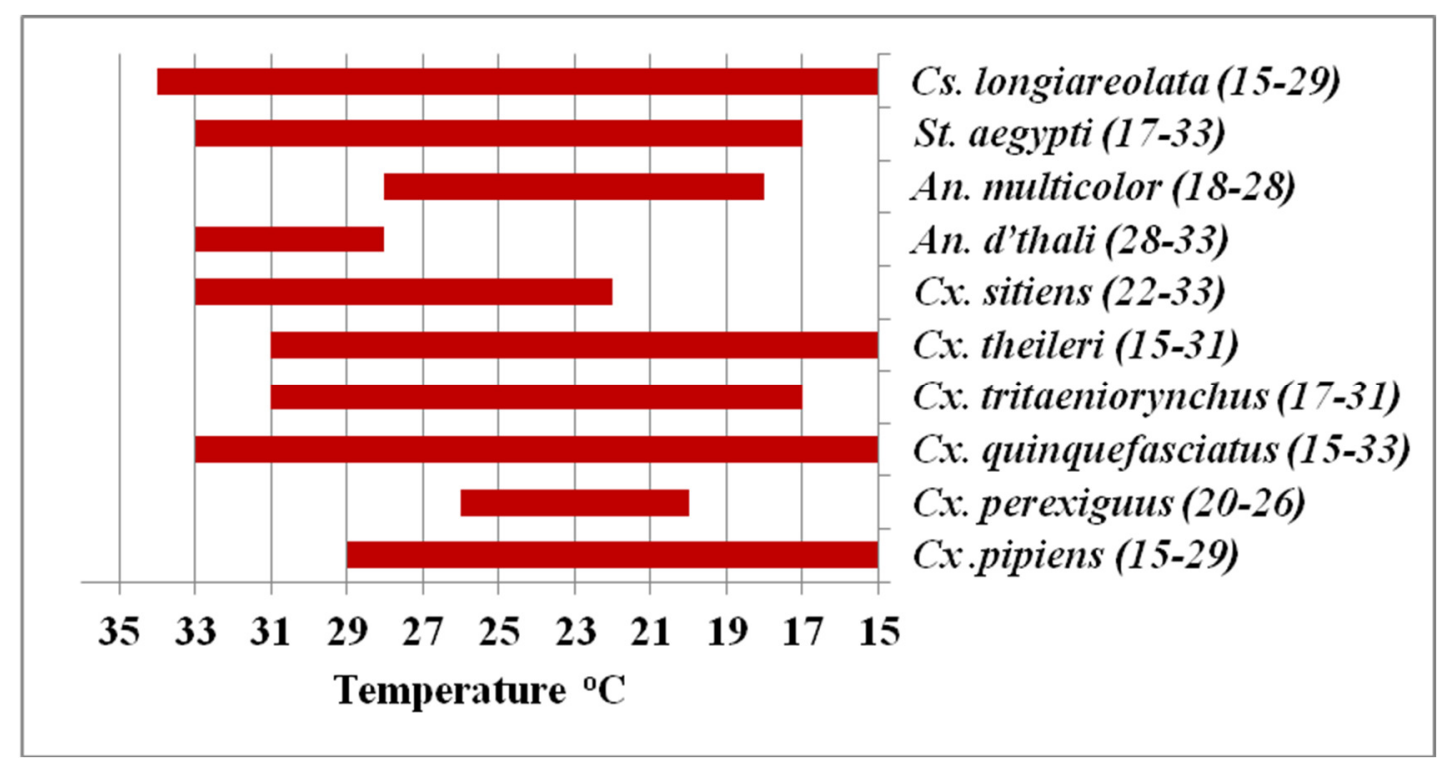

Fig. 2: Ranges of the breeding water temperature for reported larval species in all study areas

MacGregor (1927) recorded acidophile and alkalinophile mosquito laval species. For the reported species, the observed $\mathrm{pH}$ ranges (Figure 3 ) indicate that St. aegypti (4.2 to 9.3), Cx. pipiens (4.5 to 9.1), Cx. quinquefasciatus (5.0 to 9.5) and Cs. longiareolata (5.0 to 8.8 ) breed in either acidic or alkaline water (overall range: 4.2 to 9.5 ). The observed acidic to alkaline range is similar to 6.4-9.0 observed by Gad and Salit (1972) in the Red Sea, Egypt and 5.0-8.7 for Cx. pipiens, Cx. perexiguus and Oc. caspius in Cairo (Kenwy et al., 2013). While $C x$. sitiens $(7.0$ to 9.5), $C x$. tritaeniorynchus (7.3 to 9.1), An. multicolor (7.5 to 9.6), An. d'thali (7.5 to 8.6), Cx. theileri (8.0 to 9.6) and $C x$. perexiguus (8.1 to 8.8 ) breed entirely in alkaline water (overall range: 7.0 to 9.6). Cx. torrentium collected only from water had $\mathrm{pH}$ of 8.5. Although some breeding was observed in acidic water however, most of larval breeding was in alkaline water in agreement with the observations of Kirkpatrick (1925), kenawy and El Said (1990), Kenawy et al. (1998) and Abdel-Hamid et al. (2013) who indicated that mosquito breeding water in several Egyptian Governorates was mostly alkaline ( $>7)$. 


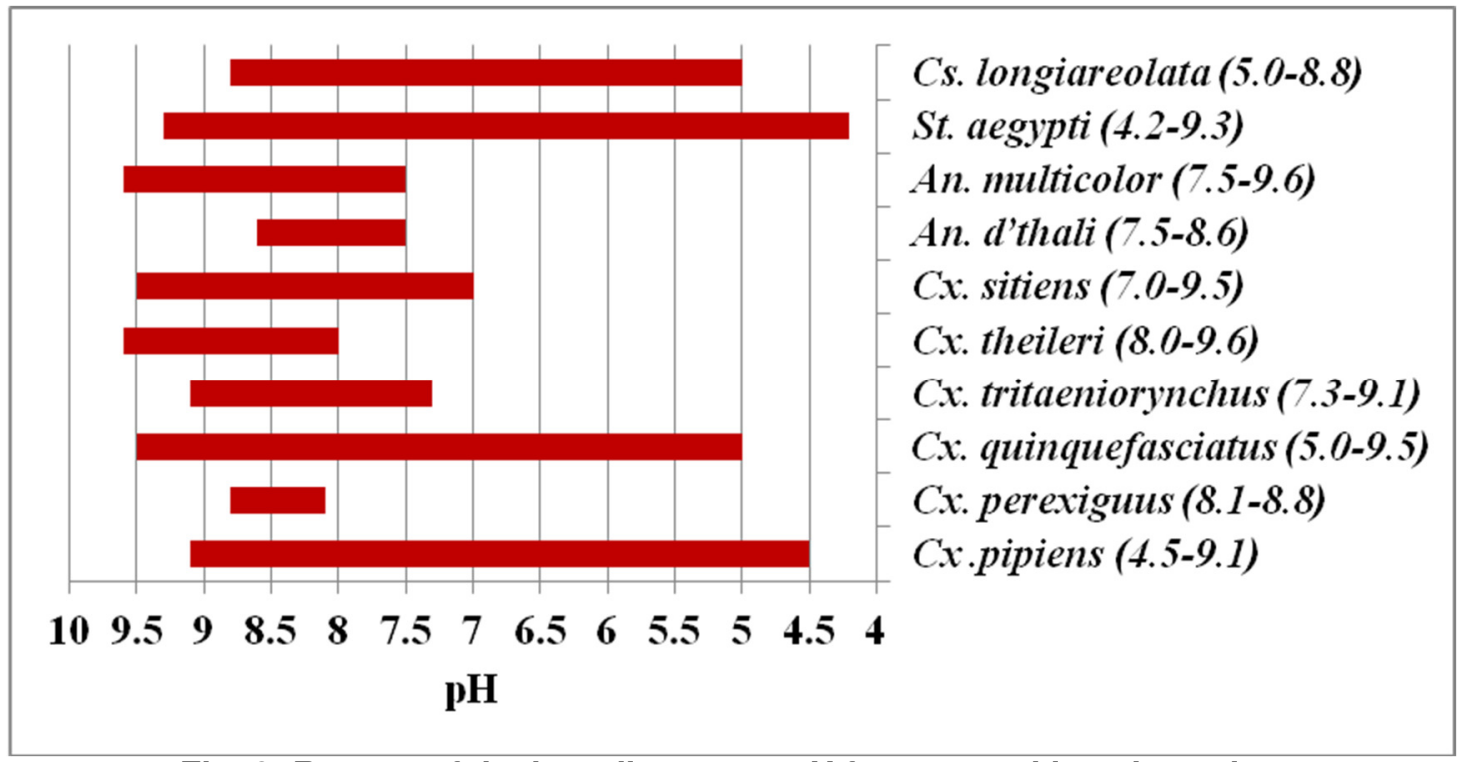

Fig. 3: Ranges of the breeding water pH for reported larval species in all study areas

For the breeding water salinity, no available data for Saudi Arabian mosquitoes as do for other countries. Based on water salinity, Kirkpatrick (1925) classified mosquito fauna of Egypt to purely fresh water breeders, purely salt water and more or less indifferent. In the present study, the eleven larval species generally have a salinity range of 154 to $1990 \mathrm{ppm}$ (ca. 0.02 to $0.20 \%$ ) indicating that these species breed in fresh / brackish water in agreement with the observation of Abdel-Hamid et al. (2011b) for Cx. pipiens and Cx. perexiguus in ElIsmailia and Kenawy et al. (2013) for five species (CX. pipiens, Cx. perexiguus, Cx. pusillus, Oc. caspius, and
Cs. longiareolata) in Cairo, Egypt. The observed salinity ranges for the reported species (Figure 4) indicate that: St. aegypti (154 to $1690 \mathrm{ppm}$ ), Cx. tritaeniorynchus (210$1866 \mathrm{ppm}$ ), Cx. quinquefasciatus (340 to $1752 \mathrm{ppm}$ ), Cx. theileri (340 to $1990 \mathrm{ppm}$ ) and Cs. longiareolata (360 to $1620 \mathrm{ppm}$ ) had wider ranges than Cx. pipiens (611 to $1972 \mathrm{ppm}$ ), Cx. perexiguus (676 to $1227 \mathrm{ppm}$ ), Cx. sitiens (700 to $1500 \mathrm{ppm}$ ), An. d'thali (710 to 840 ppm), and An. multicolor (962 to $1830 \mathrm{ppm}$ ). CX. torrentium collected only from water had salinity of 907 ppm.

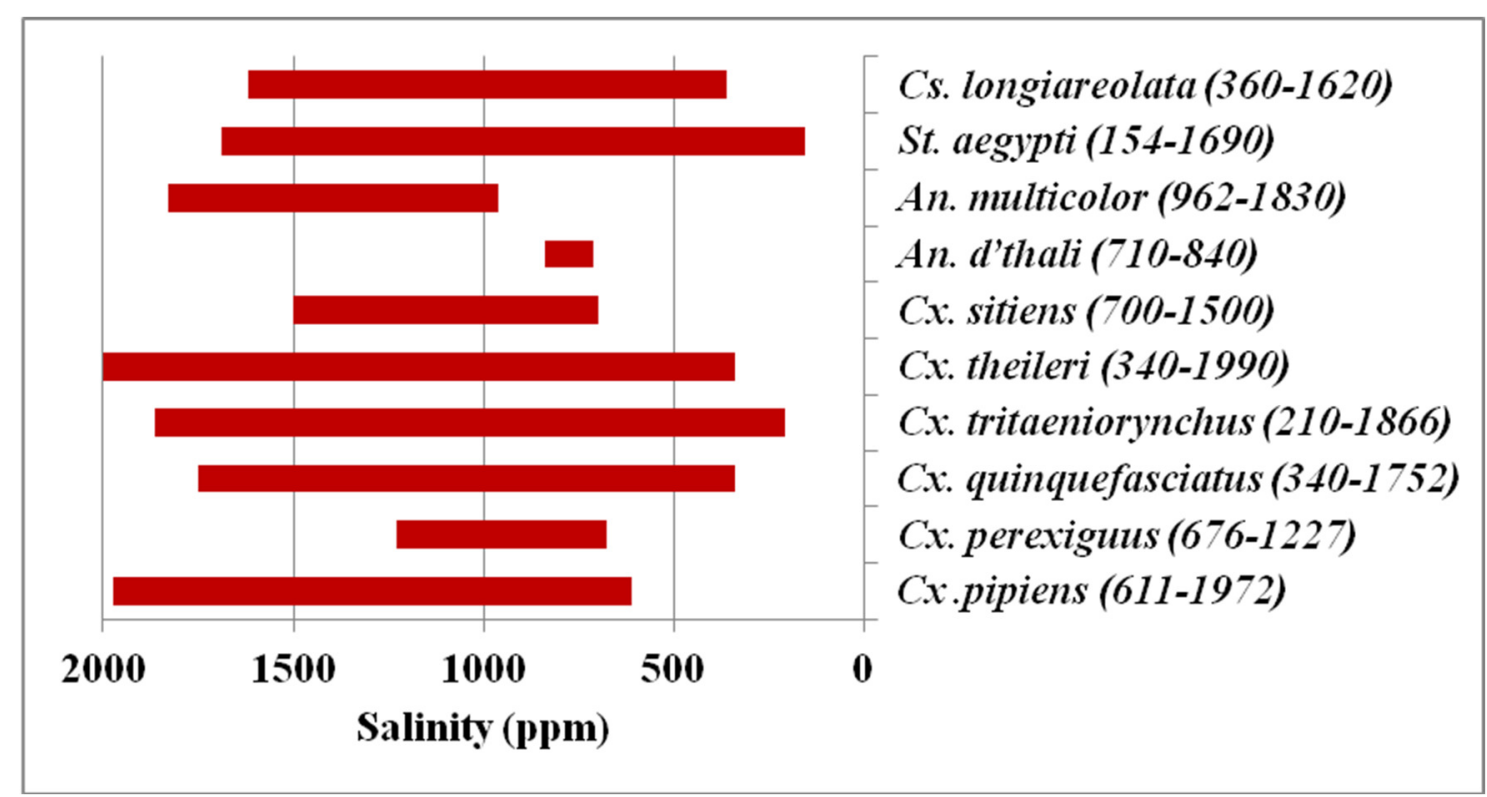

Fig. 4: Ranges of the breeding water salinity for reported larval species in all study areas 


\section{Influence of the Breeding Water Temperature, pH and Salinity on Larval Density}

Multiple Regression analysis was used to examine the relation of larval density (No / SU) with the temperature, $\mathrm{pH}$ and salinity of the breeding water. Results (Table 1) indicate that:

Table 1: Multiple regression analysis for the effect of temperature, $\mathrm{pH}$ and salinity on larval densities of the reported mosquito species.

\begin{tabular}{|l|c|c|c|}
\hline \multirow{2}{*}{ Species } & \multicolumn{3}{|c|}{ The slope (regression coefficient, b) } \\
\cline { 2 - 4 } & Temperature & $\mathbf{p H}$ & Salinity \\
\hline Cx.pipiens & 1.959 & -0.133 & 0.040 \\
\hline Cx. quinquefasciatus & $2.641^{*}$ & $2.442^{\star *}$ & -0.017 \\
\hline Cx. tritaeniorynchus & $4.241^{\star *}$ & $23.600^{* *}$ & 0.016 \\
\hline Cx. theileri & 1.236 & -18.059 & -0.002 \\
\hline Cx. sitiens & 6.151 & $-74.570^{\star *}$ & 0.074 \\
\hline An. multicolor & 0.516 & -3.167 & 0.013 \\
\hline St. aegypti & 1.045 & -4.016 & -0.009 \\
\hline Cs. longiareolata & 0.323 & 3.503 & 0.002 \\
\hline
\end{tabular}

${ }^{\star} P<0.05,{ }^{\star \star} P<0.01(t$ - test)

(1) Densities of all species were directly related to temperature i.e., increase as temperature increases. With the exception of $C x$. quinquefasciatus $(b=2.64$, $\mathrm{P}<0.05)$ and $C x$. tritaeniorynchus $(\mathrm{b}=4.24, \mathrm{P}<0.01)$, the $b$ values (0.32 to 6.15) of the other species (Cx. pipiens, Cx. theileri, Cx. sitiens, An. multicolor, St. aegypti and Cs. longiareolata) were insignificantly different $(P>0.05)$. However, in the Eastern Province, Jemal and Al-Thukair (2016) observed that mosquito larval abundance has a negative correlation with temperature (mean correlation coefficient $=-0.773$ for the whole Province: -0.075 to 0.941 for the 8 study sites). The authors indicated that regression model of the 3 climatic factors (temperature, relative humidity and rainfall) accounted for $64.3 \%$ ( $R=$ 0.643 ) of the variance in larval abundance and the remaining $35.7 \%$ attributed to other factors such as the presence of vegetation, waste materials and water reservoirs such as ditches.

(2) Larval densities of $C x$. pipiens, Cx. theileri, $C x$. sitiens, An. multicolor and St. aegypti were indirectly related to $\mathrm{pH}(\mathrm{b}=-0.13$ to -74.57$)$, while those of $C x$. quinquefasciatus, Cx. tritaeniorynchus and Cs. longiareolata were directly related to $\mathrm{pH}(\mathrm{b}=2.44$ to 23.60) and (3) Larval densities of Cx. quinquefasciatus, $C x$. theileri and St. aegypti were indirectly related to salinity ( $b=-0.002$ to -0.017 ), while those of $C x$. pipiens, Cx. tritaeniorynchus, Cx. sitiens, An. multicolor and Cs. longiareolata were directly related to salinity $(b=0.002$ to 0.074). No comparable study for Saudi mosquitoes except that of Al-Ahmed et al. (2010) which suggested that the salt content and $\mathrm{pH}$ have no significant effects on the larval distribution of the different species in Najran. However, several studies in Egypt and other countries support the present findings. Kenawy et al. (1996) in El Sharkia Governorate, Egypt reported that densities of $C x$. antennatus and $C x$. perexiguus significantly $(P<0.05)$ increased as a linear function of $\mathrm{pH}$ and temperature of the breeding water. Kenawy et al. (1998) in El Sharkia rice fields, Egypt observed that the relation of larval densities of $C x$. antennatus and $C x$. perexiguus were positive with $\mathrm{pH}$ and negative with temperature. Sunish and Reuben (2002) investigated the relationship of 13 abiotic variables with the abundance of $C x$. vishnui immatures in rice fields in south India and indicated a positive relation with water temperature. Abdel-Hamid et al. (2011a) in El Menoufia Governorate, Egypt found that the total larval density of $C x$. pipiens, $C x$. antennatus and $C x$. perexiguus decreased as both temp and $\mathrm{pH}$ increased $(\mathrm{P}>0.05)$. Abdel-Hamid et al. (2009, 2011b, 2013) in 3 Egyptian Governorates indicated that the overall larval density of $C x$. pipiens, $C x$. antennatus and $C x$ perexiguus increases as temperature increase $(\mathrm{P}<0.05)$ while it decreases $(P>0.05)$ as pH increase. Kenawy et al. (2013) indicated that densities of both $C x$. pipiens and $C x$. perexiguus in Cairo had positive relation with temperature and $\mathrm{pH}$ $(P>0.05)$ and negative relation with salinity $(P<0.05)$. Kadhem et al. (2014) showed that Aedes caspius had insignificant positive correlation with $\mathrm{pH}$ and temperature, Culex pipiens had insignificant negative correlation with $\mathrm{pH}$ and temperatureand Culiseta longiareolata had significant negative correlation with $\mathrm{pH}$ $(\mathrm{P}<0.05)$ and temperature $(\mathrm{P}<0.01)$.

\section{CONCLUSION}

The obtained different ranges of temperature, $\mathrm{pH}$ and salinity and relations of such factors with the abundance of the reported larval species may be of help in designing and implementing control program based 
on environmental manipulation or modifying habitat characteristics that will be effective in controlling targeted mosquito species specially disease vectors.

COMPETING INTERESTS: The authors declare that there is no conflict of interests.

\section{AUTHORS' CONTRIBUTIONS:}

MIH: Participated in preparation of draft article and approved final Ms.

HAA: Carried out field studies.

MS: Participated in preparation of draft article and approved final Ms

MAK: Partly participated in field studies, carried out statistical analysis and prepared the draft and final Ms.

\section{REFERENCES}

Abdel-Hamid YM, Soliman MI and Allam KM (2009). Spatial distribution and abundance of culicine mosquitoes in relation to the risk of filariasis transmission in El- Sharqiya Governorate, Egypt. Egypt. Acad. J. Biol. Sci., 1: 39-48.

Abdel-Hamid YM, Soliman Ml and Kenawy MA (2011a). Geographical distribution and relative abundance of culicine mosquitoes in relation to transmission of lymphatic filariasis in El Menoufia Governorate, Egypt. J. Egypt. Soc. Parasitol., 41: 109-118.

Abdel-Hamid YM, Soliman MI and Kenawy MA (2011b). Mosquitoes (Diptera: Culicidae) in relation to the risk of disease transmission in El Ismailia Governorate, Egypt. J. Egypt. Soc. Parasitol., 41: 347-356.

Abdel-Hamid YM, Soliman MI and Kenawy MA (2013). Population ecology of mosquitoes and the status of bancroftian filariasis in El Dakahlia Governorate, the Nile Delta, Egypt. J. Egypt. Soc. Parasitol., 43: 103113.

Abdoon A-MMO and Alshahrani AM (2003). Prevalence and distribution of Anopheline mosquitoes in malaria endemic areas of Asir Region, Saudi Arabia. East Mediterr. Hlth. J., 9: 240-247.

Al Ahmad AM, Sallam MF, Khuriji MA, Kheir SM and Azari-Hamidian S (2011). Checklist and pictorial key to fourth-instar larvae of mosquitoes (Diptera: Culicidae) of Saudi Arabia. J. Med. Entomol., 48: 717-737.

Alahmed AM, Al Kuriji MA, Kheir SM, Al Ahmedi SA, Al Hatabbi MJ and Al Gashmari MA (2009). Mosquito fauna (Diptera: Culicidae) and seasonal activity in Makkah Al Mukarramah Region, Saudi Arabia. J. Egypt. Soc. Parasitol., 39: 991-1013.

Alahmed AM, Al Kuriji MA, Kheir SM, Al Sogoor DAD and Salama HAS (2010). Distribution and seasonal abundance of mosquitoes (Diptera: Culicidae) in the
Najran Region, Saudi Arabia. Studia dipterologica, 17:13-27.

Al-Ali $\mathrm{KH}$, El-Badry AA, Eassa AH, Al-Juhani AM, AlZubiany SF and El-Kheir DI (2008). A study on Culex species and Culex transmitted diseases in AlMadinah Al-Munawarah, Saudi Arabia. PUJ, 1: 101108.

Al Ghamdi K, Alikhan M, Mahayoub J and Afifi ZI (2008). Studies on identification and population dynamics of Anopheline mosquito from Jeddah, Saudi Arabia. Biosci. Biotech. Res. Commun., 1: 19-24.

Alikhan M, Ghamdi KA and Mahyoub JA (2014). Aedes mosquito species in western Saudi Arabia. J. Insect Sci., 14: 69.

Al-Seghayer SM, Kenawy MA and Ali OTE (1999). Malaria in the Kingdom of Saudi Arabia: Epidemiology and control. Sci. J. King Faisal University (Special issue), 1: 6-20.

Bayoh MN and Lindsay SW (2003). Effect of temperature on the development of the aquatic stages of Anopheles gambiae sensu stico (Diptera: Culicidae). Bull. Entomol. Res., 93: 375-381.

Bayoh MN and Lindsay SW (2004). Temperature-related duration of aquatic stages of the Afrotropical malaria vector mosquito Anopheles gambiae in the laboratory. Med. Vet. Entomol.18: 174-179.

Daggy RH (1959). Malaria in oases of eastern Saudi Arabia. Am. J. Trop. Med. Hyg., 8: 223-291.

El-Badry AA and Al-Ali KH (2010). Prevalence and seasonal distribution of dengue mosquito, Aedes aegypti (Diptera: Culicidae) in Al Madinah AlMunawwarah, Saudi Arabia. J. Entomol., 7: 80-88.

Gad AM and SALIT AM (1972). Mosquitoes of the Red Sea, Egypt. J. Med. Entomol., 9: 581-582.

Gimnig JE, Ombok M, Kamau L, Hawley WA (2001). Characteristics of larval anophelinae (Diptera: Culicidae) habitats in western Kenya. J. Med. Entomol., 38: 282-288.

Hammer $\varnothing$, Harper DAT and Ryan PD (2001). Past: Paleontological statistics software package for education and data analysis. Available from: http://www.nhm2.uio.no/norlex/past/Past.exe.

Jemal Yand Al-Thukair AA (2016). Combining GIS application and climatic factors for mosquito control in Eastern Province, Saudi Arabia. Saudi Journal of Biological Sciences, in Press, Available on line 13 April 2016 , http://dx.doi.org/10.1016/j.sjbs.2016.04.001.

Jupp PG, Kemp A, Grobbelaar A, Leman P, Burt FJ, Alahmed AM, Al Mujalli D, Al Khamees $M$ and Swanepoel R (2002). The 2000 epidemic of Rift Valley fever in Saudi Arabia: mosquito vector studies. Med. Vet. Entomol., 16: 245-252.

Kadhem ZA, Al-Sariy JS and Ali SM (2014). Seasonal distribution study of mosquito species (Culicidae: Diptera) in Al- Naamania salt Basin north western Al Kut city / Iraq. Wasit Journal for Science \& Medicine., 7: 124-135. 
Kenawy MA, Ammar SE and Abdel-Rahman HA (2013). Physico-chemical characteristics of the mosquito breeding water in two urban areas of Cairo Governorate, Egypt. JEAR, 45:e17.

Kenawy MA, Rashed SS and Teleb SS (1996). Population ecology of mosquito larvae (Diptera: Culicidae) in Sharkiya Governorate, Egypt. J. Egypt. Ger. Soc. Zool., 21: 121-142.

Kenawy MA, Rashed SS and Teleb SS (1998). Characterization of rice field mosquito habitats in Sharkia Governorate, Egypt. J. Egypt. Soc. Parasitol., 28: 449-459.

Khater EI, Sowilem MM, Sallam MF and Alahmed AM (2013). Ecology and habitat characterization of mosquitoes in Saudi Arabia. Trop. Biomed., 30: 409427.

Kheir SM, Al Ahmed AM, Al Kuriji MA and Al Zubyani SF (2010). Distribution and seasonal activity of mosquitoes (Diptera: Culicidae) in Al Madinah Al Munwwarah Region, Saudi Arabia. J. Egypt. Soc. Parasitol., 40: 215-227.

Kirkpatrick TW (1925). The mosquitoes of Egypt. Egyptian Government, Antimalaria Commission, Government Press, Cairo, pp. 244.

Macgregor ME (1927). Mosquito surveys. Welcome Bureau of Scientific Research, London. pp. 282.

Mahyoub JA, Al-Harbi OS, Al-Ghamdi KM, Mangoud $\mathrm{AAH}$ and Al-Solami HM (2015). Population dynamics of different mosquito genera and species in Makkah city, Saudi Arabia. Biosci. Biotech. Res. Comm., 8: 116-125

Mattingly PF and Knight KL (1956). The mosquitoes of Arabia. Bull. Brit. Mus. (Nat. Hist.) Entomol., 4: 89141.

Miller BR, Godsey MS, Crabtree MB, Savage HM, AlMazrao Y, Al-Jeffri MH, Abdoon AM, Al-Seghayer SM, Al-Shahrani AM and Ksiazek TG (2002). Isolation and genetic characterization of Rift Valley
Fever virus from Aedes vexans arabiensis, Kingdom of Saudi Arabia. Emerg. Infect. Dis., 8: 1492-1494.

Omar MS (1996). A survey of bancroftian filariasis among South-East Asian expatriate workers in Saudi Arabia. Trop. Med. Int. Hlth., 1: 155-160.

Overgaard HJ, Tsuda Y, Suwonkerd $W$ and Takagi M (2001). Characteristics of Anopheles minimus (Diptera: Culicidae) larval habitats in northern Thailand. Environ. Entomol., 10: 134-141.

Oyewole 1O, Momoh OO, Anyasor GN, Ogunnowo AA, Ibidapo CA, Oduola OA, Obansa JB and Awolola TS (2009). Physico-chemical characteristics of Anopheles breeding sites: Impact on fecundity and progeny development. Afr. J. Environ. Sci. Technol., 3: $447-452$

Piyaratnea MK, Amerasinghea FP, Amerasinghea PH and Konradsena F (2005). Physico-chemical characteristics of Anopheles culicifacies and Anopheles varuna breeding water in a dry zone stream in Sri Lanka. J. Vect. Borne Dis., 42: 61-67.

Seghal S and Pillai MK (1970). Preliminary studies on the chemical nature of mosquito breeding waters in Delhi. Bull. WHO., 42: 647-650.

Sunish IP and Reuben R (2002). Factors influencing the abundance of Japanese encephalitis vectors in rice fields in India - II. Biotic. J. Med. Entomol., 16: 1-9.

White GB (1974). Anopheles gambiae complex and disease transmission in Africa. Trans. Roy. Soc. Trop. Med. Hyg., 68: 278-301.

WHO "World Health Organization" (1975). Manual on practical entomology in malaria. Part (I) Vector bionomics and organization of anti-malaria activities. WHO Division of Malaria and other Parasitic Diseases, WHO, Geneva. pp. 160.

Wills WM, Jakob WL, Francy DB, Oertley RE, Anani E, Calisher CH and Monath TP (1985). Sindbis virus isolations from Saudi Arabian mosquitoes. Trans R. Soc.Trop. Med. Hyg., 79: 63-66. 